\title{
Trace metal distribution in pelagic fish species from the north-west African coast (Morocco)
}

\author{
Imane Afandi $\cdot$ Sophia Talba $\cdot$ Ali Benhra $\cdot$ Samir Benbrahim $\cdot$ \\ Rachid Chfiri • Maylis Labonne • Hicham Masski • Raymond Laë • \\ Luis Tito De Morais • Mohammed Bekkali • Fatima Zohra Bouthir
}

Received: 15 November 2017 / Accepted: 2 April 2018/Published online: 5 June 2018

(C) The Author(s) 2018

\begin{abstract}
In the current study, ten elements contents (Fe, $\mathrm{Zn}, \mathrm{Mn}, \mathrm{Cu}, \mathrm{Cr}, \mathrm{Co}, \mathrm{Ni}, \mathrm{Cd}, \mathrm{Pb}$ and $\mathrm{Hg}$ ) have been measured in muscle and liver of four pelagic fish species (Engraulis encrasicolus, Sardina pilchardus, Scomber japonicus and Trachurus trachurus) from the north-west African coast (South Atlantic Moroccan coast), collected during summer and autumn seasons (July and December 2013, respectively). Significant differences in metal contents were found between the different species $(p<0.05)$. Metals levels were also much higher in liver than those recorded in muscle tissues. The concentrations of $\mathrm{Fe}, \mathrm{Zn}, \mathrm{Cd}, \mathrm{Co}, \mathrm{Cu}$ and $\mathrm{Pb}$ were significantly higher in mackerel liver $(p<0.05)$. While, in muscle, anchovy presents a higher content of $\mathrm{Mn}, \mathrm{Cu}, \mathrm{Cr}, \mathrm{Ni}$ and $\mathrm{Pb}$. A high level of cadmium was recorded in liver of the different species which can be attributed to an anthropogenic source (phosphate industry) and to natural sources (upwelling activities). The main concentration of toxic elements $(\mathrm{Cd}, \mathrm{Pb}$ and $\mathrm{Hg}$ ) recorded in the four edible muscles of pelagic fish species, under study, were below the established values by the European Commission Regulations and show that their effect on the consumers health can be considered as negligible.
\end{abstract}

Keywords South Atlantic coast of Morocco · Pelagic fish · Trace metals · Bioaccumulation · Upwelling

\section{Introduction}

The metal pollution of the marine ecosystem has always been admitted as a serious environmental issue (Blakas et al. 1982; Tariq et al. 1991). Among environmental pollutants, metals are of particular concern; due to their potential toxic effect and ability to bioaccumulate in aquatic compartment (Censi et al. 2006). Trace metals are naturally and lowly present in seawater but their concentration levels have increased due to anthropogenic pollutants (Kargin et al. 2001). Fish and other aquatic organisms are persistently exposed to

\author{
I. Afandi $(\bowtie) \cdot$ M. Bekkali \\ Faculty of Sciences Ain Chock, Hassan II University, Maarif, B. P. 5366, 20100 Casablanca, Morocco \\ e-mail: imaneafandi@hotmail.com \\ I. Afandi $\cdot$ S. Talba $\cdot$ A. Benhra $\cdot$ S. Benbrahim $\cdot$ R. Chfiri $\cdot$ H. Masski $\cdot$ F. Z. Bouthir \\ National Institute of Halieutic Research, Street Sidi Abderrahmane Club equestre Ould Jmel, 20100 Casablanca, Morocco \\ S. Talba \\ Faculty of Sciences Ben M'sik, Avenue du Cdt Driss Lharti, 20700 Casablanca, Morocco \\ M. Labonne · R. Laë · L. Tito De Morais \\ UMR LEMAR 6539, IUEM, Place copernic, Plouzané, 29820 Brest, France
}


chemicals in polluted and contaminated waters (Burger et al. 2002) and are exposed to accumulate considerable amounts of toxic elements from their living environment (Suhaimi et al. 2005). Thus, accumulation occurs in the tissues of fish and can be transferred to higher trophic levels via food chain. Therefore, it is important to evaluate the concentration of toxic elements in fish, because it is representing a potential health risks to the fish organisms and to the higher trophic level organism like humans that potentially consume them ( $\mathrm{Li}$ et al. 2015; $\mathrm{Vu}$ et al. 2017). Actually, numerous studies have been carried out on trace metals contamination of different species of edible fish (Prudente et al. 1997; Kucuksezgin et al. 2001; Lewis et al. 2002; El Morhit et al. 2009; Chahid et al. 2014; Afandi et al. 2015; Diop et al. 2016).

The Moroccan coast, with the Canary Current upwelling ecosystem (CanC), constitute one of the four main eastern boundaries upwelling ecosystems (EBUEs) of the world, which give rise to highly productive ecosystems and fisheries (Pauly and Christensen 1995). In this area, the primary production exceeds $300 \mathrm{~g} \mathrm{~cm}^{-2}$ year $^{-1}$ (Carr 2002; Carr and Kearns 2003). Based on this high production, various commercially and socio-economically important fisheries take place in this area such as small pelagic fishes (Boëly and Fréon 1979). Small pelagic fishes are the major target in the fisheries in the Northwest coast of Africa. Over the last decade, total catch has been fluctuating around an average of 1.8 million tones (FAO 2012). However, this fishing potential has experienced a decrease in the recent decades. Beyond the impact of fishing activities (Kifani et al. 2008), the Moroccan coast is under threat from the impacts of anthropogenic pollution (UNEP 1999, 2006) and global changes that will affect the water resources either directly (Biswas 2008), by potentiating effects of contaminants (Parry et al. 2007; Couillard et al. 2008), through variations in ocean dynamics and upwelling activities.

In this study, four pelagic fish species including (Engraulis encrasicolus (anchovy), Sardina pilchardus (sardine), trachurus trachurus (horse mackerel) and Scomber japonicus (mackerel)) were selected. These fish species are of particular importance due to their intermediate position in the food web but also for their abundance. They are of crucial economic and biological importance, especially as they are the most consumed species by the Moroccan population. All these species have a gregarious behavior; however, they represent different spatial distribution and diet behaviors. Anchovy is found in the North Atlantic, North and Mediterranean Sea. It lives in coastal waters up to $150 \mathrm{~m}$ of depth. It is a planktonophagous species that mainly feeds on phytoplankton (diatoms, dinoflagellates...) and zooplankton (copepods, radiolaria, eggs, larvae...) (INRH 2013). In the Atlantic Ocean, sardines are distributed from the North Sea to the Mauritanian coast and can even reach the waters of Senegal (Fréon and Stéquert 1979). It lives in coastal waters up to $120 \mathrm{~m}$ of depth. It is a planktonophagous species whose diet consists largely of phytoplankton. Mackerel has a cosmopolitan distribution including warm and temperate waters of the Atlantic, Indian and Pacific Oceans and adjacent seas. It is essentially a near coastal species, with a vertical distribution ranging between 0 and $300 \mathrm{~m}$ of depths. Mackerel show a diet that varies according to its stage of life, from a zoo planktonophagous during larval and post-larval stage to piscivory as adult (small pelagic fish, particularly anchovies). The European horse mackerel is distributed mainly on the continental shelf of the Northeast Atlantic. Along the West African coast, this species is distributed over the coast at over $300 \mathrm{~m}$ of depth, with preference for the deepest areas of the continental shelf (FAO 2001). His diet is mainly composed of decapods (shrimps), juvenile anchovies, myctophids and carangids (FAO 1983; COPACE 1984).

Thus, the purpose of this work (involved in the framework of EPURE project research program) is to determine and compare the concentrations of $\mathrm{Zn}, \mathrm{Fe}, \mathrm{Cu}, \mathrm{Pb}, \mathrm{Cd}, \mathrm{Cr}, \mathrm{Co}$ and $\mathrm{Hg}$ in the liver and muscle of four small pelagic fish species from the south Atlantic Moroccan coast during two periods of upwelling phenomena, in July season of strong upwelling and December season of weak upwelling. The objective is also to describe the differences of the concentrations of trace metals between species, between upwelling seasons and to compare the results with guidelines set down by the European Commission Regulation (European Commission Regulation (EC) 2008, 2014, 2015) for the safe consumption limits of fish and the other studies. 


\section{Materials and methods}

\section{Sampling}

Four pelagic marine fish (Engraulis encrasicolus, Sardina pilchardus, Scomber japonicus and Trachurus trachurus) were collected on cruises of the R/V ANTEA in summer and autumn season (July and December 2013). The samples were caught with a pelagic trawl at 27 locations in southern Moroccan coastal waters $\left(22-30^{\circ} \mathrm{N}\right)($ Fig. 1). The four species were sampled according to their availability and presence in sufficient quantity. After collection, the total length $(\mathrm{cm})$ and body weight $(\mathrm{g})$ of fishes were measured (Table 1). The dissection of samples was done on board, then three replicate, composed of tissues from five individuals, of muscle and liver were removed with ceramic knife and frozen at $-20^{\circ} \mathrm{C}$. In the laboratory, samples were freeze dried for $72 \mathrm{~h}$ at $-55{ }^{\circ} \mathrm{C}$. Then each dried fish sample was homogenized by mixing in rotating glass bottle, and stored until analysis.

Samples preparation and analytical method

The digestion procedure is carried out according to the Association of Official Analytical Chemists (AOAC) method: 2000. The total mercury levels were determined by an Automated Mercury Analyzer, Aula 254 (Gold trap). The analyses of the other metals were performed on an inductively coupled plasma mass spectrometer (ICP-Q-MS X-Series 2, Thermo Scientific) in Ocean Spectrometry Pole at IUEM (Brest, France). Typically, $400 \mu \mathrm{L}$ of the archive solution were added to $800 \mu \mathrm{L}$ of $0.80 \mathrm{M} \mathrm{HNO}_{3}$ (Merck ${ }^{\circledR}$-Ultrapur Grade) spiked with in (1 ppb) into acid-washed $13 \mathrm{~mm}$ o.d. polypropylene tube with rounded bottom (VWR). Samples were introduced to a PFA-ST nebulizer/via a modified SC-Fast introduction system consisting of an SC-2 auto sampler, a six-port valve and a vacuum rinsing pump.

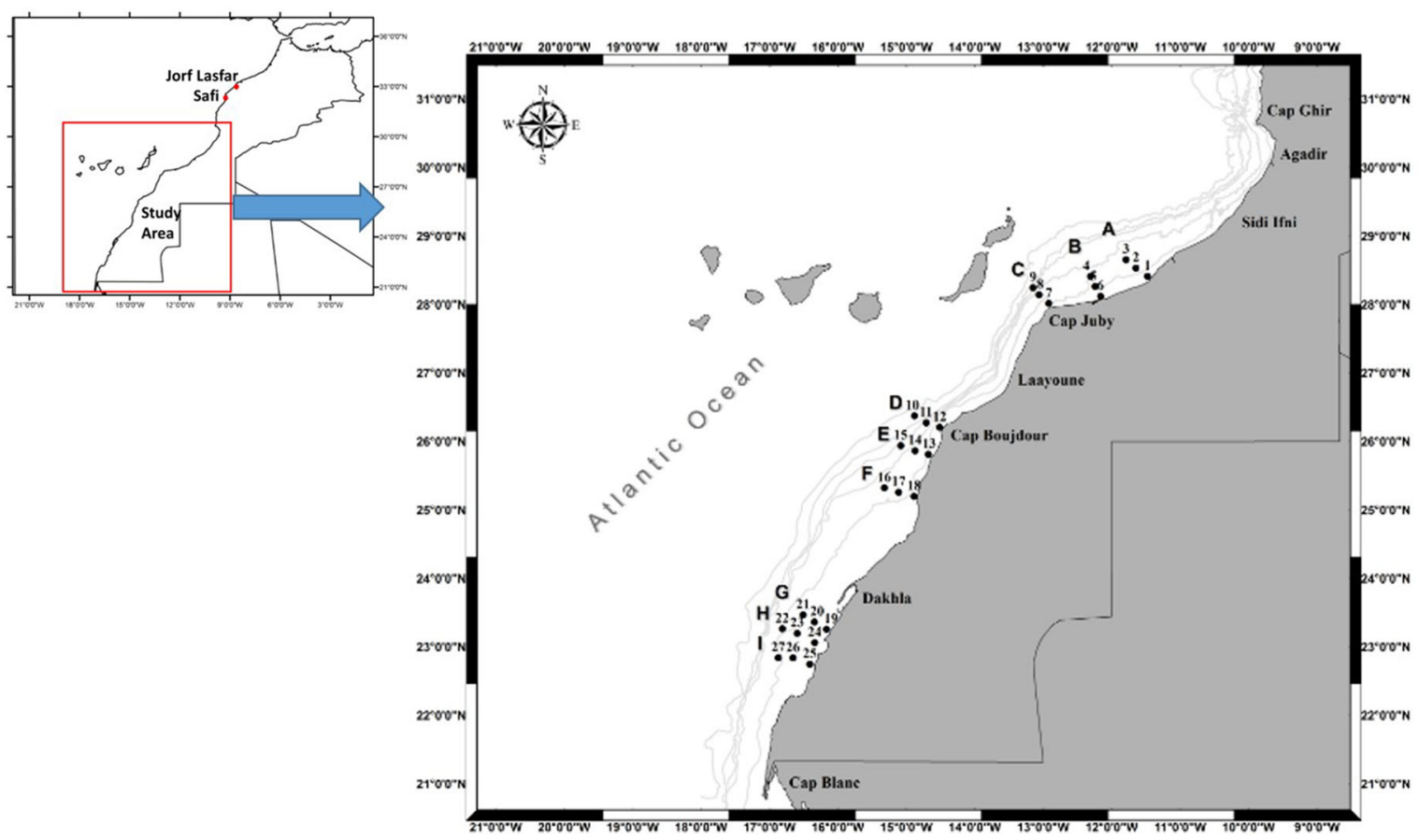

Fig. 1 Study area and sampling location 
Table 1 The mean length and weight of fish species

\begin{tabular}{lrr}
\hline Species & Length $(\mathrm{cm})$ & Weight $(\mathrm{g})$ \\
\hline Anchovy (Engraulis encrasicolus) & $13.5 \pm 1.15$ & $19.3 \pm 5.05$ \\
Sardine (Sardina pilchardus) & $19 \pm 2.40$ & $43.7 \pm 14.40$ \\
Mackerel (Scomber japonicus) & $23 \pm 5.50$ & $65.3 \pm 15.80$ \\
Horse Mackerel (Trachurus trachurus) & $21.5 \pm 4.50$ & $92.4 \pm 40.60$ \\
\hline
\end{tabular}

Quality assurance and statistical analysis

Stock standard solutions were prepared gravimetrically from mono and multielemental certified standards (Plasma Cal, SCP Science). A 7-point external standard curve was prepared by serial dilutions and analyzed every 30 samples. Indium and rhodium were added as internal standards.

Precision (degree of reproducibility) and accuracy (degree of veracity) of our procedure were controlled through analyses of a certified reference materials Dorm-4 (fish protein, National Research Council, Canada), using the same digest procedures used for samples. Repeated measurements of these reference materials (every 15 samples) yielded a precision (relative standard deviation) between 8 and 15\%. Accuracy was extremely good with a variation ranging from 5 to $8 \%$ between our measurements and the certified values.

All statistical calculations were carried out with XLSTAT for Windows (Version 2015.1.03.15945). Statistical significance was defined at $95 \%(p<0.05)$. The whole data were subjected to statistical analysis. The inter-species and seasonal differences in element concentrations between fish were performed with a one-way ANOVA, followed by post hoc Turkey tests. Pearson's correlation coefficients were used to examine relationships between the elements in the muscle and liver of the fish species.

\section{Results}

The concentration of ten metals elements measured in liver and muscle tissues are reported for each species in Tables 2 and 3. The results show that whatever the species, metals were more concentrated in the livers than in muscles. We found significant variation in the element concentrations in liver and muscle tissues (one-way ANOVA test, $p<0.05$ ). Considering the average concentration of metals in all pelagic species, the metals in livers are present in the following order: $\mathrm{Fe}>\mathrm{Zn}>\mathrm{Cd}>\mathrm{Cu}>\mathrm{Mn}>\mathrm{Co}>\mathrm{Ni}>\mathrm{Hg}>\mathrm{Cr}>\mathrm{Pb}$. However, the sequence of metal content in muscle present the following order $\mathrm{Fe}>\mathrm{Zn}>\mathrm{Cu}>\mathrm{Mn}>\mathrm{Ni}>\mathrm{Cr}>$ $\mathrm{Cd}>\mathrm{Hg}>\mathrm{Pb}-\mathrm{Co}$. The order of metal accumulation in both organs showed that $\mathrm{Cd}$ and $\mathrm{Co}$ are much more accumulated in liver than in muscle. Moreover, for all species, the sequence of toxic trace element was as follows: $\mathrm{Cd}>\mathrm{Hg}>\mathrm{Pb}$ in liver and muscle tissues.

In both organs, iron showed the highest metal level in studied fish, with the highest concentration recorded in mackerel tissues $\left(1158.1 \pm 514.8\right.$ in liver and $68.52 \pm 30.7 \mu \mathrm{g} \mathrm{g}^{-1}$ d.w. in muscle). Following iron, zinc showed the second highest levels. In liver of mackerel, $\mathrm{Zn}$ represent the highest level $\left(129.65 \pm 22.15 \mu \mathrm{g} \mathrm{g}^{-1}\right.$ d.w.), however, in muscle the highest concentration of $\mathrm{Zn}$ was observed in anchovy and mackerel (36.9 \pm 7.5 and $37.5 \pm 10.9 \mu \mathrm{g} \mathrm{g}^{-1}$ d.w., respectively). The maximum content of $\mathrm{Cd}$ and $\mathrm{Cu}$ was observed in liver of mackerel $\left(50.07 \pm 20.3 ; 28.30 \pm 6.37 \mu \mathrm{g} \mathrm{g}^{-1}\right.$ d.w., respectively). In muscle Cd content was high in mackerel $\left(0.198 \pm 0.3 \mu \mathrm{g} \mathrm{g}^{-1}\right.$ d.w. $)$, however, the maximum level of $\mathrm{Cu}$, was observed in anchovy $\left(6.18 \pm 1.6 \mu \mathrm{g} \mathrm{g}^{-1}\right.$ d.w.). Levels of toxic metals in livers show that $\mathrm{Cd}$ and $\mathrm{Pb}$ are more accumulated by mackerel; however, $\mathrm{Hg}$ is more accumulated by anchovy $\left(0.49 \pm 0.00 \mu \mathrm{g} \mathrm{g}{ }^{-1}\right.$ d.w.). The levels of $\mathrm{Pb}$ showed a weak variation in muscles of the different fish species. In spite its small size, anchovy had Cd levels slightly higher of those found in horse mackerel. Furthermore, mercury level was significantly high in muscle of horse mackerel $(p<0.05)$. Concentrations of $\mathrm{Ni}$ were high in liver of anchovy and horse mackerel $(0.521 \pm 0.28$; $0.437 \pm 0.52 \mu \mathrm{g} \mathrm{g}^{-1}$ d.w., respectively) and in muscle of anchovy $\left(0.33 \pm 0.28 \mu \mathrm{g} \mathrm{g}{ }^{-1}\right.$ d.w. $)$. Co present the same behavior as $\mathrm{Cd}$ with high level in liver of mackerel $\left(1.59 \pm 0.8 \mu \mathrm{g} \mathrm{g}^{-1}\right.$ d.w.) and muscle of anchovy and mackerel $\left(0.064 \pm 0.013 ; 0.068 \pm 0.037 \mu \mathrm{g} \mathrm{g}^{-1}\right.$ d.w., respectively). Results of concentration of Mn showed that the highest concentrations are registered in liver and muscle of anchovy $\left(4.95 \pm 0.67,2.0 \pm 0.3 \mu \mathrm{g} \mathrm{g}^{-1}\right.$ 


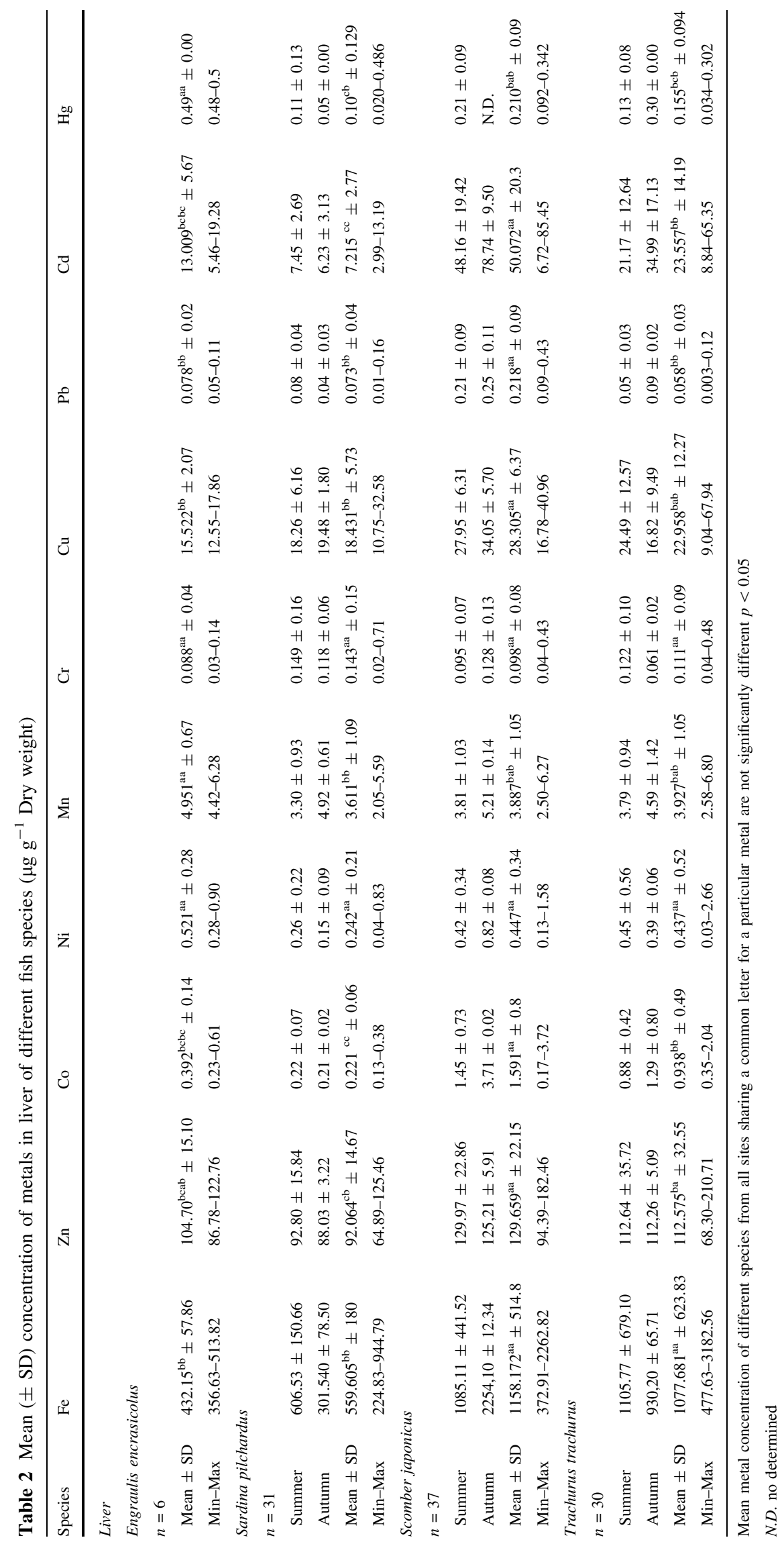




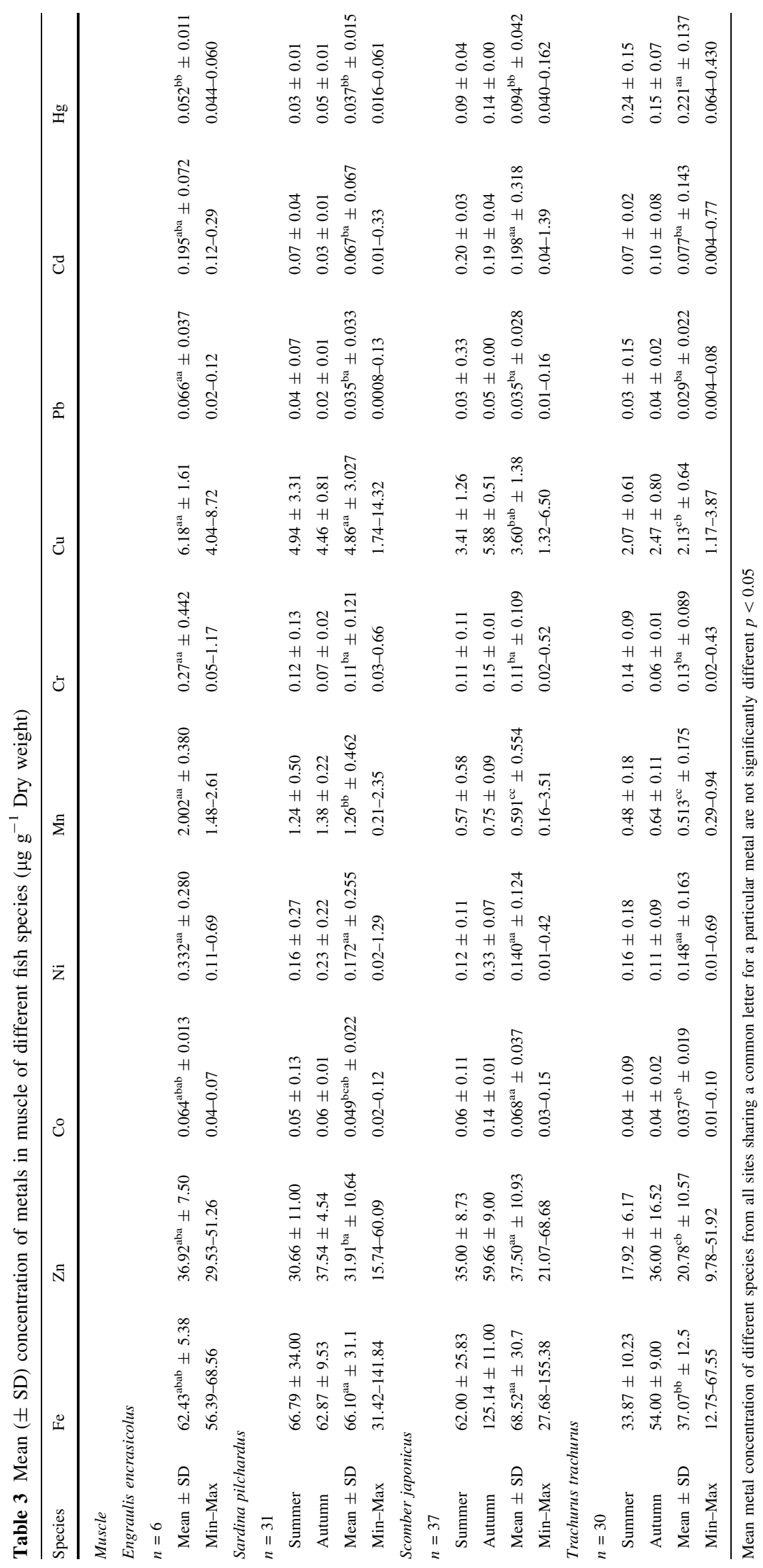


d.w., respectively). Finally, $\mathrm{Cr}$ represent the higher concentrations in liver of Sardine and horse mackerel $\left(0.143 \pm 0.15 \mu \mathrm{g} \mathrm{g}^{-1} \mathrm{~d}\right.$.w $)$ however, in muscle anchovy represent the maximum content $\left(0.27 \pm 0.4 \mu \mathrm{g} \mathrm{g}^{-1}\right.$ d.w). The concentrations of $\mathrm{Fe}, \mathrm{Zn}, \mathrm{Cd}, \mathrm{Co}, \mathrm{Cu}$ and $\mathrm{Pb}$ were significantly higher in mackerel liver $(p<0.05)$. Whereas $\mathrm{Mn}, \mathrm{Cu}, \mathrm{Cr}, \mathrm{Ni}$ and $\mathrm{Pb}$ were higher in muscle of anchovy (Tables 2, 3).

The mean concentration of metals in tissues of sardine, mackerel and horse mackerel during summer and autumn seasons (anchovy was not represented due to unavailability during warm season) are giving in Figs. 2 and 3 and Tables 2 and 3. During both seasons, the results showed that the concentration of metals were higher in liver than in muscle. Therefore, there was no clear seasonal pattern in metal concentrations (Figs. 2, 3). The results showed that, indeed, sardine concentrations of $\mathrm{Fe}, \mathrm{Pb}$ were significantly higher $(p<0.05)$ during summer season, whereas $\mathrm{Mn}$ were significantly higher $(p<0.05)$ during autumn season. For mackerel, concentrations of $\mathrm{Fe}, \mathrm{Co}$ and $\mathrm{Cd}$ were significantly higher $(p<0.05)$ during autumn season. For horse mackerel only $\mathrm{Pb}$ concentrations that were significantly higher $(p<0.05)$ during autumn season. In muscle, concentrations of $\mathrm{Fe}, \mathrm{Co} \mathrm{Ni}, \mathrm{Cu}, \mathrm{Zn}$ were significantly higher $(p<0.05)$ during autumn season for mackerel. However, only $\mathrm{Zn}$ and $\mathrm{Fe}$ were significantly higher $(p<0.05)$ during autumn season for horse mackerel. No significant differences were observed for the other elements studied here.

Inter-elemental relationships in fish tissues (inter-metal correlation) were assessed by the mean of Person's correlation coefficient. Tables 4 and 5 show values of correlation coefficients among metal concentrations. A high significant positive correlation was observed in tissue samples for the trace metal pairs of $\mathrm{Fe}$ and $(\mathrm{Zn}, \mathrm{Cu}$, $\mathrm{Ni}, \mathrm{Co}), \mathrm{Zn}$ and $(\mathrm{Cu}, \mathrm{Co}), \mathrm{Mn}$ and $(\mathrm{Cu}, \mathrm{Cr}, \mathrm{Ni}), \mathrm{Cu}$ and $(\mathrm{Ni}, \mathrm{Co})$ in liver. In addition, a high significant correlations were found in muscle between $\mathrm{Fe}$ and $(\mathrm{Zn}, \mathrm{Cu}, \mathrm{Co}, \mathrm{Cd}), \mathrm{Zn}$ and $(\mathrm{Cu}, \mathrm{Co}, \mathrm{Cd}), \mathrm{Cu}$ and $(\mathrm{Co}, \mathrm{Pb}$, $\mathrm{Cd})$; $\mathrm{Co}$ and $(\mathrm{Pb}, \mathrm{Cd})$ and $\mathrm{Pb}-\mathrm{Cd}$.

\section{Discussion}

In this study, the investigation of trace metal contamination levels in fish from the southern Atlantic Moroccan coast showed the presence of differences of contamination between species and considered organs, as well as
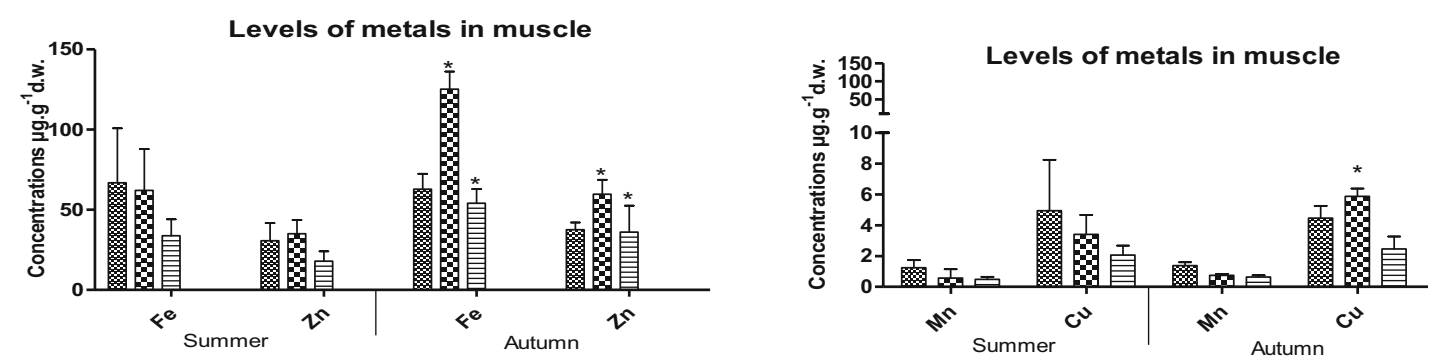

Sardina pilchardus 5 Scomber japonicus $\Longrightarrow$ Trachurus trachurus

Sardina pilchardus

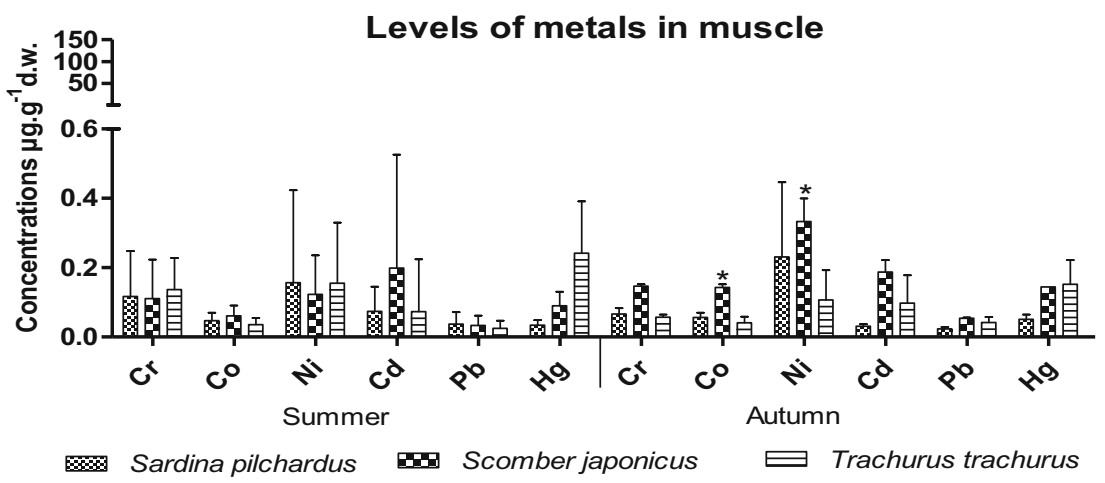

Fig. 2 Seasonal variation in mean metals concentrations $( \pm S D)$ in muscle of the three pelagic fish species (asterisk denote significant differences between season) 

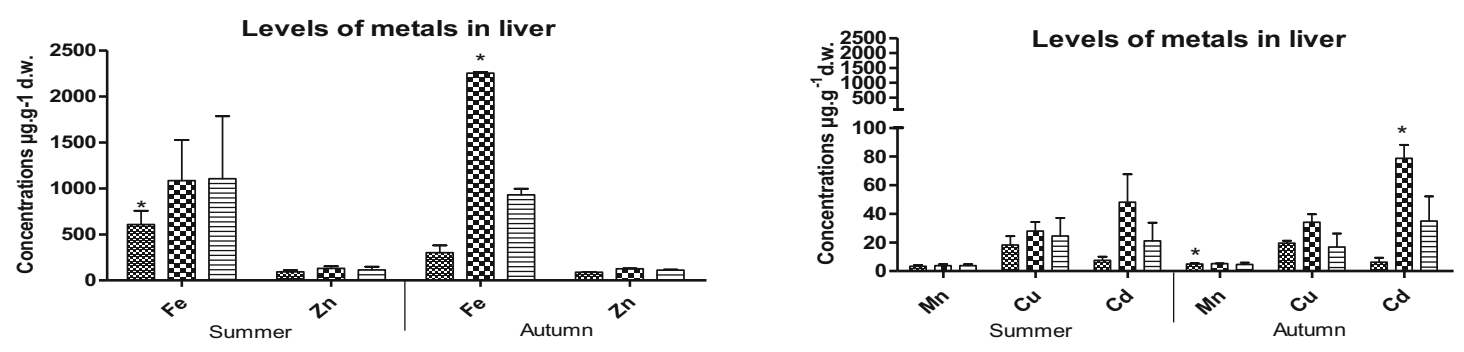

Sardine pilchardus $\rightleftharpoons$ scomber japonicus $\rightleftharpoons$ Trachurus trachurus

Sardina pilchardus

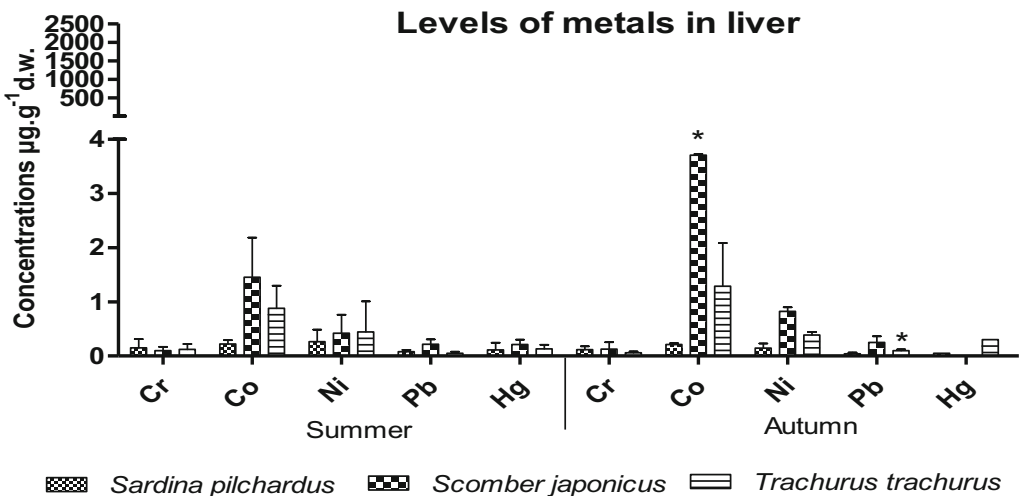

Fig. 3 Seasonal variation in mean metals concentrations $( \pm S D)$ in liver of the three pelagic fish species (asterisk denote significant differences between season)

Table 4 Pearson product-moment correlation coefficients between trace metals in the muscle tissue of fishes

\begin{tabular}{|c|c|c|c|c|c|c|c|c|c|c|}
\hline Metal & $\mathrm{Fe}$ & $\mathrm{Zn}$ & $\mathrm{Mn}$ & $\mathrm{Cr}$ & $\mathrm{Cu}$ & $\mathrm{Ni}$ & Co & $\mathrm{Pb}$ & $\mathrm{Cd}$ & $\mathrm{Hg}$ \\
\hline $\mathrm{Fe}$ & 1 & & & & & & & & & \\
\hline $\mathrm{Zn}$ & 0.727 & 1 & & & & & & & & \\
\hline $\mathrm{Mn}$ & 0.473 & 0.362 & 1 & & & & & & & \\
\hline $\mathrm{Cr}$ & 0.325 & 0.158 & 0.428 & 1 & & & & & & \\
\hline $\mathrm{Cu}$ & 0.848 & 0.656 & 0.659 & 0.458 & 1 & & & & & \\
\hline $\mathrm{Ni}$ & 0.614 & 0.452 & 0.515 & 0.792 & 0.720 & 1 & & & & \\
\hline Co & 0.753 & 0.644 & 0.263 & 0.329 & 0.672 & 0.481 & 1 & & & \\
\hline $\mathrm{Pb}$ & 0.396 & 0.335 & 0.463 & 0.279 & 0.532 & 0.394 & 0.329 & 1 & & \\
\hline $\mathrm{Cd}$ & 0.178 & 0.073 & -0.051 & 0.193 & 0.030 & 0.087 & 0.177 & 0.077 & 1 & \\
\hline $\mathrm{Hg}$ & -0.313 & -0.400 & -0.365 & 0.074 & -0.339 & 0.004 & -0.117 & -0.151 & -0.034 & 1 \\
\hline
\end{tabular}

Bold value indicate significant levels at $p<0.05$

very significant variations between the elements of metals analyzed. Two groups of elements were determined for all the data obtained. It is well known that some of the trace elements control important biological processes by facilitating the binding of molecules to their receptor sites on cell membrane, e.g., $\mathrm{Fe}, \mathrm{Cu}, \mathrm{Zn}$, $\mathrm{Mn}, \mathrm{Cr}, \mathrm{Ni}$ and $\mathrm{Co}$, representing a group of essential elements to metabolic activities and physiological functions which are present in all animal tissues. However, other metals are known to be potentially toxic, i.e., $\mathrm{Hg}, \mathrm{Pb}$ and $\mathrm{Cd}$, and may be of natural or anthropogenic origin, representing a group of toxic elements.

Metal concentrations in fish organs

The results demonstrated that, whatever the species, elements show higher concentrations in liver than in muscle tissue (Tables 2, 3) as reported in other studies (Diop et al. 2016). Metal accumulation in fish organs 
Table 5 Pearson product-moment correlation coefficients between trace metals in the liver tissue of fishes

\begin{tabular}{|c|c|c|c|c|c|c|c|c|c|c|}
\hline Variables & $\mathrm{Fe}$ & $\mathrm{Zn}$ & Mn & $\mathrm{Cr}$ & $\mathrm{Cu}$ & $\mathrm{Ni}$ & $\mathrm{Co}$ & $\mathrm{Pb}$ & $\mathrm{Cd}$ & $\mathrm{Hg}$ \\
\hline $\mathrm{Fe}$ & 1 & & & & & & & & & \\
\hline $\mathrm{Zn}$ & 0.787 & 1 & & & & & & & & \\
\hline $\mathrm{Mn}$ & 0.137 & 0.510 & 1 & & & & & & & \\
\hline $\mathrm{Cr}$ & -0.105 & 0.013 & 0.226 & 1 & & & & & & \\
\hline $\mathrm{Cu}$ & 0.661 & 0.708 & 0.267 & 0.199 & 1 & & & & & \\
\hline $\mathrm{Ni}$ & 0.234 & 0.463 & 0.395 & -0.029 & 0.197 & 1 & & & & \\
\hline Co & 0.686 & 0.668 & 0.198 & -0.165 & 0.735 & 0.398 & 1 & & & \\
\hline $\mathrm{Pb}$ & 0.472 & 0.492 & -0.191 & -0.227 & 0.675 & 0.169 & 0.631 & 1 & & \\
\hline $\mathrm{Cd}$ & 0.687 & 0.651 & 0.033 & -0.233 & 0.747 & 0.205 & 0.764 & 0.876 & 1 & \\
\hline $\mathrm{Hg}$ & 0.173 & 0.335 & 0.457 & -0.161 & 0.280 & 0.217 & 0.311 & 0.264 & 0.363 & 1 \\
\hline
\end{tabular}

Bold value indicate significant levels at $p<0.05$

relay on the physiological role of the organs (Uysal et al. 2008). Liver represent an organ with high metabolic activities and accumulate more elements than organ with lower metabolic activities like muscle (Ploetz et al. 2007). These organs with high metabolic activities contain metal-binding proteins involved in the reduction of trace metal functions, like metallothioneins in the liver, allowing them to accumulate a significant higher level of element than the muscle tissue (Roesijadi 1996; JariC et al. 2011). In our study, all metals concentrations in all fish species show the following trend, liver $>$ muscle.

Metal concentrations in different fish species

In our study, the results showed that fish exhibited wide inter-specific variations in metals accumulation in both organs. The liver tissue of predatory fish (mackerel and horse mackerel) contained significantly higher levels of $\mathrm{Fe}, \mathrm{Co}, \mathrm{Cu}, \mathrm{Zn}, \mathrm{Cd}$ (Table 2), due to their feeding at the higher trophic levels, therefore, by the bioaccumulation and biomagnification of the elements through the food chain. Many studies attributed high metal accumulation to the feeding habit of the fish. Mackerel and horse mackerel feed on fish, crustaceans and cephalopods. Therefore, there is an evidence for metal bioaccumulation and biomagnification; however, evidence for Cd biomagnifications is inconsistent (Vieira et al. 2011).

In the edible muscles of the pelagic species, anchovy was found to have significant higher content of $\mathrm{Cr}$, $\mathrm{Mn}, \mathrm{Ni}, \mathrm{Cu}$ and $\mathrm{Pb}$. Actually; it is well known that metal concentrations in fish tissues are related to metal contents in environment. Thus, this finding in anchovy could be linked to feeding on zooplankton since it is able to accumulate a high metal content. Topping (1973) have also reported that fish species feeding on plankton contain higher concentration of trace metals than bottom feeding fish. Gundogdu et al. (2016) reported the same results with high metals content in muscle of E. encrasicolus from Black sea than content found in muscle of T. trachurus and M. barbatus. The reason for high metal concentrations in small fish could also be due to the metal complex with the mucus in skin that is impossible to be purified completely from fish tissue before the analysis. Thus, for small fish the skin may be an important site for the uptake of metals due to their high surface area to body ratio.

Nevertheless, the bioaccumulation process of metals in organisms can also influenced by biotic factors, defining for each species and for each development stage, the ecological characteristics (habitat. diet) and the structural and functional properties of the biological barriers that separate living organisms from their environment and controlling metal absorption. (Boudou and Ribeyre 1997; Andres et al. 2000; Barron 2003).

Metal accumulation patterns

The general order of monitored metal bioaccumulation in pelagic fish was $\mathrm{Fe}>\mathrm{Zn}>\mathrm{Cd}>\mathrm{Cu}>\mathrm{Mn}>$ $\mathrm{Co}>\mathrm{Ni}>\mathrm{Hg}>\mathrm{Cr}>\mathrm{Pb}$ in liver and $\mathrm{Fe}>\mathrm{Zn}>\mathrm{Cu}>\mathrm{Mn}>\mathrm{Ni}>\mathrm{Cr}>\mathrm{Cd}>\mathrm{Hg}>\mathrm{Pb}-\mathrm{Co}$ in muscle tissue. We observed that the essential metals showed the same order of magnitude, however, only the toxic elements presented different order depending on fish environment. In comparison with data reported for 
pelagic fish from other locations, the observed amount of sequences are different from that indicated by Copat et al. (2013) in muscle of pelagic fish (muscle of anchovy, mackerel and horse mackerel) from Eastern Mediterranean sea $(\mathrm{Zn}>\mathrm{Mn}>\mathrm{Ni}>\mathrm{Cr}>\mathrm{Pb}>\mathrm{Cd})$, Canli and Atli (2003) in sardine tissues $(\mathrm{Fe}>\mathrm{Zn}>$ $\mathrm{Pb}>\mathrm{Cu}>\mathrm{Cr}>\mathrm{Cd}$ ), Ersoy and Çelik (2009) in muscle $(\mathrm{Fe}>\mathrm{Zn}>\mathrm{Cu}>\mathrm{Mn}>\mathrm{Ni}>\mathrm{Pb}>\mathrm{Cr}>\mathrm{Cd}$ ) and liver of mackerel $(\mathrm{Fe}>\mathrm{Zn}>\mathrm{Cu}>\mathrm{Mn}>\mathrm{Cd}>\mathrm{Pb}>\mathrm{Ni}>\mathrm{Cr}$ ) both from the Mediterranean sea, and Bilandžić et al. (2011) in muscle tissue of sardine and mackerel from Adriatic Sea $(\mathrm{Cu}>\mathrm{Hg}>\mathrm{Pb}>\mathrm{Cd})$. From these observations, we have noted that cadmium element is the less accumulated metal, at the opposition of our results, which show a large accumulation of cadmium especially in the liver. Cadmium is particularly concentrated in liver of the four studied fish species (Table 2). Data from a previous study showed that cadmium level in liver of various species is less than $10 \mathrm{mg} / \mathrm{kg}$ d.w., and more often less than $1 \mathrm{mg} / \mathrm{kg} \mathrm{d} . \mathrm{w}$. (Romeo et al. 1999; Henry et al. 2004; Diop et al. 2016). Cadmium were already founded at high levels in fish and mollusks from West African coastal areas such as the Mauritanian water (Romeo et al. 1999; Sidoumou et al. 2005), Moroccan coast (Benbrahim et al. 2006; Maanan 2008; El Morhit et al. 2013) or Senegalese coast (Bodin et al. 2013; Diop et al. 2016). These high concentrations of Cd were attributed to natural origins, such as upwelling of deep waters, which takes place along the Western Atlantic coast (Romeo et al. 1999). Auger et al. (2015), has demonstrated that coastal upwelling in Western Atlantic coast, represent the main natural origin of cadmium enrichment of marine ecosystems, whereas the main anthropogenic origin is the phosphate industry effluents. Actually, Morocco is the second phosphate producer in the world. About 27 million tons of phosphate ores are extracted and processed annually to produce phosphoric acid and phosphorus-based fertilizers ("Annual Report, Office Chérifien des Phosphates, Maroc," 2012; Gaudry et al., 2007). The phosphoric acid is produced, from the chemical reaction between sulphuric acid and phosphate ores. During the reaction, calcium sulphate (phosphogypsum), is produced and spread out into the ocean (Auger et al. 2015).The phosphogypsum resultant from production of phosphoric acid and phosphorus-based fertilizers contain a significant abundance of crustal elements such as heavy metal, especially cadmium. Thus, the phosphate industry releases a large quantity of Cd off the coast of Morocco around Safi and Jorf-Lasfar $\left(33^{\circ} \mathrm{N}\right)$ (Gaudry et al. 2007) (Fig. 1). However, wind-inducing upwelling of intermediate water along WN African Coast and driving to a re-injection of element (Such as Cadmium) in the surface layer (Auger et al. 2015). In the same study, it has been demonstrated that potential phytoplankton Cd-uptake and Cd-bioaccumulation coincide with the upwelling enrichment and dispersion patterns in waters. This result can explain the high $\mathrm{Cd}$ content in muscle of anchovy which feed directly on plankton. The concentrations of $\mathrm{Cd}$ in liver and muscle of marine fish were in the same order of those reported in Mauritanian coast (Sidoumou et al. 2005; Romeo et al. 1999; Diop et al. 2016) and higher than those reported in pelagic fish from Moroccan coast (in central and south zone) (Chahid et al. 2014; Afandi et al. 2015) and in Portuguese water (Vieira et al. 2011).

However, metals such as $\mathrm{Fe}, \mathrm{Zn}, \mathrm{Mn}, \mathrm{Cr}, \mathrm{Ni}, \mathrm{Co}$ and $\mathrm{Cu}$ are essential elements with useful biological functions. Thus, most organisms have biochemical mechanisms control the amount of these elements into their cells. A number of studies had investigated metal contents in small pelagic fish tissues comparing with those studies, levels of $\mathrm{Cu}, \mathrm{Mn}, \mathrm{Cr}, \mathrm{Ni}, \mathrm{Fe}, \mathrm{Zn} \mathrm{Pb}$ and $\mathrm{Cd}$ reported in our study are in agreement with those found in muscle and liver of sardine from the upwelled water of Senegalese coast (Diop et al. 2016) except for Cr, Fe, $\mathrm{Pb}$ and $\mathrm{Cd}$ contents in liver which were higher than our results. Also, El Morhit et al. (2013) reported metal content in muscle of sardine collected from South Atlantic coast of Morocco, which were in same order of magnitude than our results but with higher content of Ni. However, lower metal contents were reported in muscle of anchovy $(\mathrm{Cu}, \mathrm{Fe}$, and $\mathrm{Zn})$, sardine tissues $(\mathrm{Cd}, \mathrm{Cu}, \mathrm{Co}, \mathrm{Fe}, \mathrm{Ni}, \mathrm{Pb}$, and $\mathrm{Zn})$ and in muscle of scombrus (Cd, $\mathrm{Co}, \mathrm{Cu}, \mathrm{Fe}, \mathrm{Pb}$, and $\mathrm{Zn}$ ) from Marmara Sea (Ergül and Aksan 2013). As stated above, upwelled waters, where the different studied species were collected, may be naturally rich in metal element. Metal content of fish from Mauritanian coast showed a lower concentration of $\mathrm{Cd}$ and $\mathrm{Cu}$ in sardine, mackerel and horse mackerel, and of $\mathrm{Zn}$ in sardine and mackerel, however, higher content of $\mathrm{Zn}$ were reported in muscle of horse mackerel (Romeo et al. 1999). Therefore, difference in metal accumulation can be controlled by numerous factors, corresponding to the physicochemical characteristics of the aquatic biotopes and to their natural or anthropogenic variations, influencing metals bioavailability, via the chemical speciation reactions, and their transfer and bioaccumulation behavior, in relation to the adaptive responses to the main physiological functions (e.g., respiration, osmo regulation, nutrition) (Boudou and Ribeyre 1997; Andres et al. 2000; Barron 2003). 
$\mathrm{Cd}, \mathrm{Pb}$ and $\mathrm{Hg}$ are non-essential elements with high toxic potential even at low concentrations. Legal thresholds are not available for essential elements in Europe. The European Community proposed threshold values of metal concentrations in fish muscle only for nonessential metals (e.g., $\mathrm{Cd}, \mathrm{Pb}$ and $\mathrm{Hg}$ ). The threshold values are expressed as $\mu \mathrm{g} \mathrm{g}{ }^{-1}$ wet weight and are 0.3 for $\mathrm{Pb}, 0.5$ for $\mathrm{Hg}$ and 0.05 for $\mathrm{Cd}$ in fishery products. For physiological reasons, some species accumulate this elements more than others and for these species a higher acceptable limit applies for $\mathrm{Cd}\left(0.1 \mu \mathrm{g} \mathrm{g}{ }^{-1}\right.$ wet weight for mackerel and $0.25 \mu \mathrm{g} \mathrm{g}^{-1}$ wet weight for sardine and anchovy (European Commission (EC) 2008, 2014, 2015). For an easier comparison, our results in dry weight have been converted into $\mu \mathrm{g} \mathrm{g}^{-1}$ wet weight using a conversion factor $\mathrm{CF}=\frac{\mathrm{Cd}}{\mathrm{CW}}=\frac{100}{100-\% \mathrm{H}}$ of four between wet and dry mass (Cresson et al. 2017), where $\mathrm{Cd}$ and $\mathrm{Cw}$ represent the concentrations expressed to dry and wet mass, respectively, and $\% \mathrm{H}$ is the percentage of humidity in wet tissues determined according to the Association of Official Analytical Chemists (AOAC) method: 2000. The Cd concentrations in muscle tissues were $0.05 \mu \mathrm{g} \mathrm{g}$ in anchovy and mackerel, and were $0.02 \mathrm{\mu g} \mathrm{g}^{-1}$ in sardine and horse mackerel. For $\mathrm{Pb}$, the concentrations were $0.01 \mu \mathrm{g} \mathrm{g}^{-1}$ in sardine, mackerel and horse mackerel muscles, however, the concentration were $0.02 \mu \mathrm{g} \mathrm{g} \mathrm{g}^{-1}$ in anchovy. The $\mathrm{Hg}$ concentrations in muscle tissues of anchovy, sardine, mackerel and horse mackerel were 0.013 $\mu \mathrm{g} \mathrm{g}^{-1}, 0.009 \mu \mathrm{g} \mathrm{g}^{-1}, 0.024 \mu \mathrm{g} \mathrm{g}^{-1}$ and $0.055 \mu \mathrm{g} \mathrm{g}^{-1}$, respectively. The overall $\mathrm{Cd}, \mathrm{Pb}$ and $\mathrm{Hg}$ levels in the muscle tissues of all the specimens analyzed were well under the proposed limit values. Results of cadmium contents for Sardine are comparable with those reported by Diop et al. (2016) from Senegalese Coast and higher with those reported by Chahid et al. (2013) and Vieira et al.(2011). However, these authors reported higher levels of lead and mercury in the same species. For mackerel, results found in our study present also higher cadmium contents and lower levels of $\mathrm{Pb}$ than mackerel from Atlantic Ocean in Portuguese waters, and Mediterranean Sea (Vieira et al. 2011; Falcó et al. 2006). Moreover, lower content of cadmium were reported in horse mackerel from Adriatic Sea and Atlantic Sea (Storelli 2008; Vieira et al. 2011) and higher content of Hg and Pb (Storelli 2008; Vieira et al. 2011; Mendil et al. 2010) (Table 6).

Seasonal concentration patterns

In our study area, there was no clear seasonal pattern in metal contents in fish muscles. In liver tissue, metals concentrations (except $\mathrm{Mn}$ and $\mathrm{Cu}$ ) show a decrease between summer and autumn seasons for sardine, this can probably be attributed to the upwelling intensity, which is greater during the summer season and lower during the autumn season (Makaoui et al. 2005). It is well known that upwelling phenomena contribute to metals bioavailability in environment. Bruland and Franks (1983) reported in the coastal waters of California, elevated levels of $\mathrm{Cd}, \mathrm{Cu}$ and $\mathrm{Zn}$, explaining that it could be a result from the upwelling of nutrient-rich waters. The same result was also reported by Roméo and Gnassia-Barelli (1988) for Cd, Fe and $\mathrm{Zn}$ on the Mauritanian coast. Whereas in mackerel's liver, seasonal variation of all metals concentrations (except $\mathrm{Zn}$ ) show an increase between summer and autumn seasons for mackerel. However, in horse mackerel liver no consistent patterns were recorded. Therefore, the seasonal variations of metals concentrations measured in our study could depend upon several factors such as growth and reproductive cycles and changes in water temperature (Ersoy and Çelik 2009). These variations can also be reported to the water circulation along the coast and upwelling intensity. Additionally, the differences noted in seasonal patterns between species could be due to variations in feeding habits, in spatial migration, feeding and intrinsic factors such as different rates of physiological process and uptake.

Inter-elemental relationships in fish tissues (inter-metal correlation) (Tables 4, 5) shows significant correlations among the elements ( $\mathrm{Fe}, \mathrm{Zn}, \mathrm{Mn}, \mathrm{Cr}, \mathrm{Cu}, \mathrm{Ni}, \mathrm{Co}$ and $\mathrm{Pb}$ ) in muscle and ( $\mathrm{Fe}, \mathrm{Zn}, \mathrm{Mn}, \mathrm{Cu}, \mathrm{Co}, \mathrm{Pb}$ and $\mathrm{Cd}$ ) in liver. The correlation between the different elements observed in the same tissue of fish can be explained by the similar accumulation behavior of trace elements in the fishes and their interactions (Kojadinovic et al. 2007).

\section{Conclusion}

Based on the analyses of fish samples, trace metal concentrations in fish from the south Atlantic Moroccan coast were broadly comparable to those found in similar national and international studies. In this work, there 


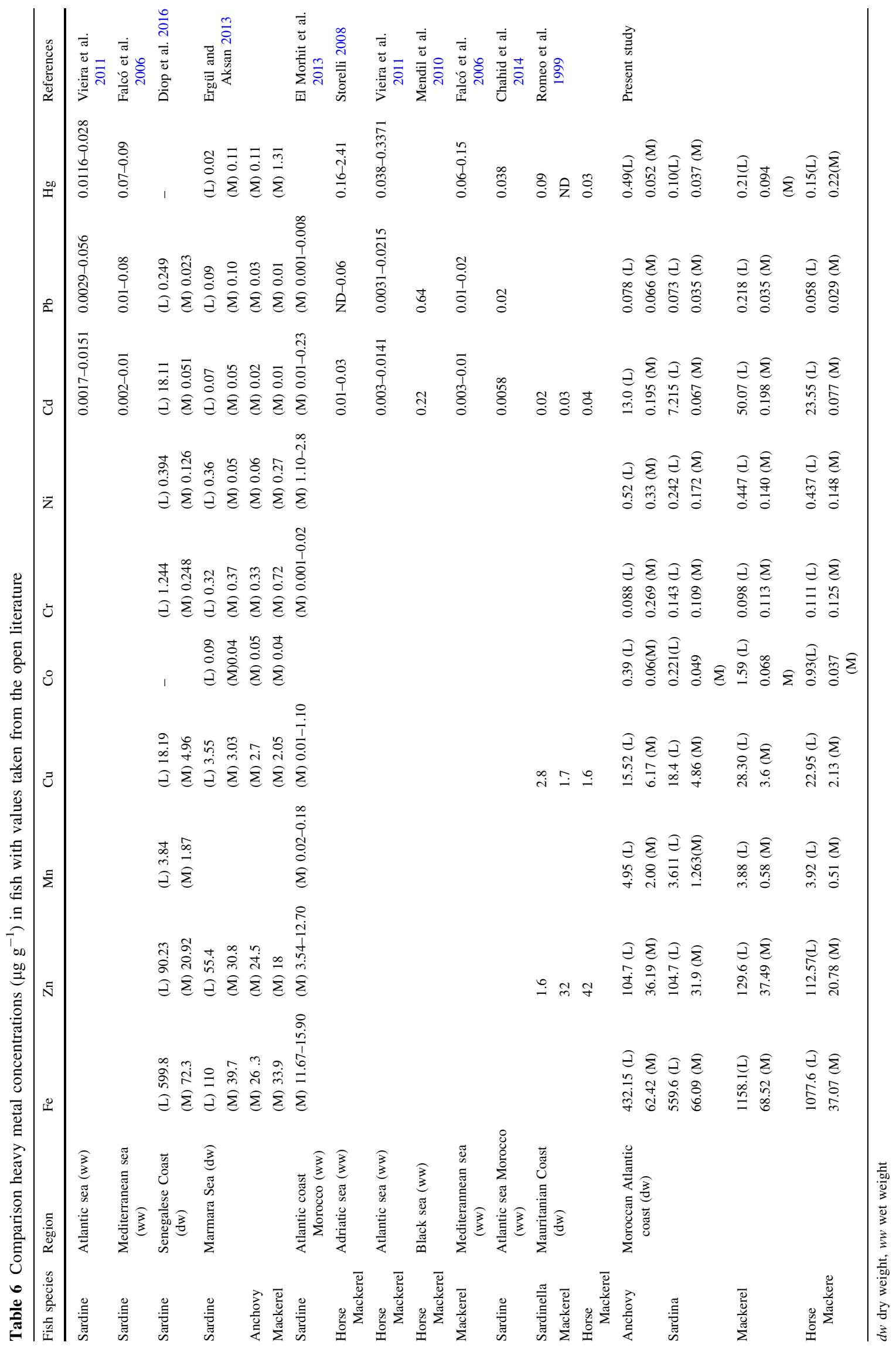


was no clear seasonal pattern in metal contents in fish muscles. However, we observed, a significant bioaccumulation behavior between species and organs. A high level of cadmium was recorded in liver of the different species which can be attributed to anthropogenic sources (phosphate industry) and to natural sources (upwelling activities). The toxic elements $(\mathrm{Cd}, \mathrm{Pb}$ and $\mathrm{Hg}$ ) recorded in edible muscle of the four pelagic fish species, were below the limit value established by the European Commission Regulation (European Commission (EC) 2008, 2014, 2015) and show that consumption of fish from the south Moroccan Atlantic coast cannot have a risk for health of consumers. However, the coastal zone and its components represent an expanding dynamic environment, which continues to be a key and a promising sector for the development of Morocco, and therefore, constant monitoring of the marine ecosystems in the southern coast sea is required by the concerned agency due to the increase of anthropogenic activities for safe supply of fish.

Acknowledgements This work was supported financially by ANR EPURE project (Trace-metal Element climatic Perturbations, Upwelling and Resources). We would like to express our gratitude to the project coordinators and the crew that participated in the survey on aboard the R/V Antea and to the engineers of the Pole Spectrometry Ocean Brest (PSO, IUEM, Brest, France) for their help running ICP-MS measurements. A special thanks go to Ms Zineb Zine El Abidine for editing English language of the whole text.

Open Access This article is distributed under the terms of the Creative Commons Attribution 4.0 International License (http:// creativecommons.org/licenses/by/4.0/), which permits unrestricted use, distribution, and reproduction in any medium, provided you give appropriate credit to the original author(s) and the source, provide a link to the Creative Commons license, and indicate if changes were made.

\section{References}

Afandi I, Chfiri R, Benhra A, Benbrahim S, Bekkali M, Bouthir FZ (2015) Heavy metal in four fish species from the Atlantic coast of Morocco. Int J Adv Res 3:368-376

Andres S, Ribeyre F, Tourencq JN, Boudou A (2000) Interspecific comparison of cadmium and zinc contamination in the organs of four fish species along a polymetallic pollution gradient (Lot River, France). Sci Total Environ 248:11-25

Annual Report, Office Chérifien des Phosphates, Maroc (2012). http://www.ocpgroup.ma/finance/rapports-publies/rapport-annuel

AOAC (2000) Official methods of analysis of AOAC international. Animal feed.Chap.4 p.5. http://webpages.icav.up.pt/PTDC/ CVTNUT/4294/2012/AOAC\%202000.pdf

Auger PA, Machu E, Gorgues T, Grima N, Waeles M (2015) Comparative study of potential transfer of natural and anthropogenic cadmium to plankton communities in the North-West African upwelling. Sci Total Environ 505:870-888

Barron MG (2003) Bioaccumulation and bioconcentration in aquatic organisms. In: Hoffman DJ, Rattner BA, Burton GA Jr, Cairns J Jr (eds) Handbook of ecotoxicology, 2nd edn. Lewis Publishers, Boca Raton, pp 877-892

Benbrahim S, Chafik A, Chfiri R, Bouthir FZ, Siefeddine M, Makaoui A (2006) Etude des facteurs influençant la répartition géographique et temporelle de la contamination des côtes atlantiques marocaines par les métaux lourds: cas du mercure, du plomb et du cadmium. Mar Life 16:37-47

Bilandžić N, Đokić M, Sedak M (2011) Metal content determination in four fish species from the Adriatic Sea. Food Chem 124:1005-1010

Biswas AK (2008) Current directions: integrated water resources development a second look. Water Int 33:274-278

Blakas IT, Tugrel S, Salhogln I (1982) Trace metal levels in fish and crustaceans from Northeastern Mediterranean coastal waters. Mar Environ Res 6:281-289

Bodin N, N'Gom-Kâ R, Kâ S, Thiaw O, De Morais LT, Le Loc'h F, Chiffoleau J-F (2013) Assessment of trace metal contamination in mangrove ecosystems from Senegal, West Africa. Chemosphere 90:150-157

Boëly T, Fréon P (1979) Les ressources pélagiques côtières, In : Les ressources halieutiques de l'Atlantique centre-est. I. Les ressources du Golfe de Guinée de l'Angola à la Mauritanie, FAO Document Technique sur les Pêches 186 (1):13-78

Boudou A, Ribeyre F (1997) Mercury in the food web: accumulation and transfer mechanisms. Met Ions Biol Syst 34:289

Bruland KW, Franks RP (1983) Mn, Ni, Cu, Zn and Cd in the western North Atlantic. Trace metals in sea water. Springer, New York, pp 395-414

Burger J, Gaines KF, Boring CS, Stephens WL, Snodgrass J, Dixon C, McMahon M, Shukla S, Shukla T, Gochfeld M (2002) Metal levels in fish from the Savannah River potential hazards to fish and other receptors. Environ Res 89:85-97

Canli M, Atli G (2003) The relationships between heavy metal (Cd, Cr, Cu, Fe, Pb, Zn) levels and the size of six Mediterranean fish species. Environ Pollut 121:129-136

Carr ME (2002) Estimation of potential productivity in Eastern Boundary Currents using remote sensing. Deep Sea Res Part II 49:59-80

Carr ME, Kearns EJ (2003) Production regimes in four Eastern Boundary Current systems. Deep Sea Res Part II 50:3199-3221

Censi P, Spoto SE, Saiano F, Sprovieri M, Mazzola S, Nardone G, Di Geronimo SI, Punturo R, Ottonello D (2006) Heavy metals in coastal water systems. A case study from the northwestern Gulf of Thailand. Chemosphere 64:1167-1176

Chahid A, Hilali M, Benlhachimi A, Bouzid T (2013) Contents of cadmium, mercury and lead in fish from the Atlantic sea (Morocco) determined by atomic absorption spectrometry. Food Chem 147:357-360 
Chahid A, Hilali M, Benlhachemi A, Kadmiri IM, Bouzid T (2014) Concentrations of heavy metals in muscle, liver and gill of Sardinapilchardus (Walbaum, 1792): risk assessment for the consumers. J Environ Occup Sci 3:47-52

European Commission Regulation (E.C.) (2008) No 629/2008 of 2 July 2008 amending Regulation (EC) No 1881/2006 setting maximum levels for certain contaminants in foodstuffs. Official Journal of the European Union. 5.L.173/6

European Commission Regulation (E.C.) (2014) No 488/2014 of 12 May 2014 amending Regulation (EC) no 1881/2006 as regards the maximum levels for cadmium in foodstuffs. Official Journal of the European Union. 5. L 138/75

European Commission Regulation (E.C.) (2015) No 2015/1005 of 25 June 2015 amending Regulation (EC) no 1881/2006 as regards the maximum levels for lead in foodstuffs. Official Journal of the European Union. 5. L 161/9

COPACE RI (1984) Les pêches dans l'Atlantique Centre-Est Recherches soviétiques sur les chinchards et les maquereaux de la zone nord du COPACE

Copat C, Arena G, Fiore M, Ledda C, Fallico R, Sciacca S, Ferrante M (2013) Heavy metals concentrations in fish and shellfish from eastern Mediterranean Sea: consumption advisories. Food Chem Toxicol 53:33-37

Couillard Y, Cattaneo A, Gallon C, Courcelles M (2008) Sources and chronology of fifteen elements in the sediments of lakes affected by metal deposition in a mining area. J Paleolimnol 40:97-114

Cresson P, Travers-Trolet M, Rouquette M, Timmerman C, Giraldo C, Lefebvre S, Ernande B (2017) Underestimation of chemical contamination in marine fish muscle tissue can be reduced by considering variable wet: dry weight ratios. Mar Pollut Bull 123(1-2):279-285

Diop M, Howsam M, Diop C, Cazier F, Goossens JF, Diouf A, Amara R (2016) Spatial and seasonal variations of trace elements concentrations in liver and muscle of round Sardinelle (Sardinellaaurita) and Senegalese sole (Soleasenegalensis) along the Senegalese coast. Chemosphere 144:758-766

El Morhit M, Fekhaoui M, Elie P, Girard P, Yahyaoui A, El abidi A, Jbilou M (2009) Heavy metals in sediment, water and the European glass eel, Anguilla anguilla (Osteichthyes: Anguillidae) from Loukkos river estuary (Morocco, eastern Atlantic). Cybium 33:219-228

El Morhit M, Belghity D, El Morhit A (2013) Metallic contamination in muscle of three fish species in the southern Atlantic coast the Laâyoune (morocco). Larhyss J 15:21-34

Ergül HA, Aksan S (2013) Evaluation of non-essential element and micronutrient concentrations in seafood from the Marmara and Black Seas. J Black Sea Mediterr Environ 19(3):312-331

Ersoy B, Çelik M (2009) Essential elements and contaminants in tissues of commercial pelagic fish from the Eastern Mediterranean Sea. J Sci Food Agric 89:1615-1621

Falcó G, Llobet JM, Bocio A, Domingo JL (2006) Daily intake of arsenic, cadmium, mercury, and lead by consumption of edible marine species. J Agric Food Chem 54:6106-6112

FAO (1983) Rapport du deuxième groupe de travail ad hoc sur les chinchards et les maquereaux de la zone Nord du CO PACE. Nouadhibou, COPACE/PACE/SERIES/83/27

FAO (2001) Rapport du groupe de travail de la FAO surl'évaluation des petits pélagiques au large de l'Afrique NordOccidentale. FAO 657:1-133

FAO (2012) Science and management of small Pelagics. FAO Fish Aquac Proc 18:1-606

Fréon P, Stéquert B (1979) Note sur la présence de Sardina pilchardus (Walb.) au Sénégal: étude de la biométrie et interprétation. Cybium 6:65-90

Gaudry A, Zeroual S, Gaie-Levrel F, Moskura M, Boujrhal F-Z, El Moursli RC, Guessous A, Mouradi A, Givernaud T, Delmas R (2007) Heavy metals pollution of the atlantic marine environment by the moroccan phosphate industry, as observed through their bioaccumulation in Ulva lactuca. Water Air Soil Pollut 178:267-285

Gundogdu A, Culha ST, Kocbas F, Culha M (2016) Heavy metal accumulation in muscles and total bodies of Mullus barbatus, Trachurus trachurus and Engraulis encrasicolus captured from the coast of Sinop, Black Sea. Pak J Zool 48:25-34

Henry F, Amara R, Courcot L, Lacouture D, Bertho ML (2004) Heavy metals in four fish species from the French coast of the Eastern English Channel and Southern Bight of the North Sea. Environ Int 30:675-683

INRH (2013) Etat des Stocks et des Pêcheries Marocaines. Rapport technique 1p

JariĆ I, ViśnjiĆ-JeftiĆ Ź, CvijanoviĆ G, GaĆiĆ Z, JovanoviĆ L, SkoriĆ S, Lenhardt M (2011) Determination of differential heavy metal and trace element accumulation in liver, gills, intestine and muscle of sterlet (Acipenserruthenus) from the Danube River in Serbia by ICP-OES. Microchem J 98:77-81

Kargın F, Dönmez A, Çoğun HY (2001) Distribution of heavy metals in different tissues of the shrimp Penaeussemiculatus and Metapenaeusmonocerus from the Iskenderun Gulf, Turkey: seasonal variations. Bull Environ Contam Toxicol 66:102-109

Kifani S, Masski H, Faraj A (2008) The need of an ecosystem approach to fisheries: the Moroccan upwelling-related resources case. Fish Res 94:36-42

Kojadinovic J, Potier M, Corre ML, Cosson PR, Bustamante P (2007) Bioaccumulation of trace elements in pelagic fish from the Western Indian Ocean. Environ Pollut 146:548-566

Kucuksezgin F, Altay O, Uluturhan E, Kontas A (2001) Trace metal and organochlorine residue levels in red mullet (Mullusbarbatus) from the Eastern Aegean, Turkey. Water Res 35:2327-2332

Lewis MA, Scott GI, Bearden DW, Quarles RL, Moore J, Strozier ED, Sivertsen SK, Dias AR, Sanders M (2002) Fish tissue quality in near-coastal areas of the Gulf of Mexico receiving point source discharges. Sci Total Environ 284:249-261

Li PF, Zhang J, Xie HJ, Liu C, Liang S, Ren YG, Wang WX (2015) Heavy metal bioaccumulation and health hazard assessment for three fish species from Nansi Lake, China. Bull Environ Contam Toxicol 94:431-436

Maanan M (2008) Heavy metal concentrations in marine molluses from the Moroccan coastal region. Environ Pollut 153:176-183

Makaoui A, Orbi A, Hilmi K, Zizah S, Larissi J, Talbi M (2005) L'upwelling de la côte atlantique du Maroc entre 1994 et 1998. CR Geosci 337:1518-1524

Mendil D, Demirci Z, Tuzen M, Soylak M (2010) Seasonal investigation of trace element contents in commercially valuable fish species from the Black sea, Turkey. Food Chem Toxicol 48:865-870 
Parry ML, Canziani OF, Palutikof JP, van der Linden PJ, Hanson CE (2007) Climate Change 2007: impacts, adaptation and vulnerability. Contribution of Working Group II to the Fourth Assessment Report of the Intergovernmental Panel on Climate Change. Cambridge University Press, Eds., Cambridge, UK

Pauly D, Christensen V (1995) Primary production required to sustain globalfisheries. Nature 374:255

Ploetz M, Fitts BE, Rice TM (2007) Differential accumulation of heavy metals in muscle and liver of a marine fish, (King Mackerel, Scomberomorus cavalla Cuvier) from the Northern Gulf of Mexico, USA. Bull Environ Contam Toxicol $78: 124-127$

Prudente M, Kim EY, Tanabe S, Tatsukawa R (1997) Metal levels in some commercial fish species from Manila Bay, the Philippines. Mar Pollut Bull 34:671-674

Roesijadi G (1996) Metallothionein and its role in toxic metal regulation. Comp Biochem Physiol Part C 113:117-123

Roméo M, Gnassia-Barelli M (1988) Donaxtrunculum and Venus verrucosa as bioindicators of trace metal concentrations in Mauritanian coastal waters. Mar Biol 99:223-227

Romeo M, Siau Y, Sidoumou Z, Gnassia-Barelli M (1999) Heavy metal distribution in different fish species from the Mauritania coast. Sci Total Environ 232:169-175

Sidoumou Z, Gnassia-Barelli M, Siau Y, Morton V, Romeo M (2005) Distribution and concentration of trace metals in tissues of different fish species from the Atlantic Coast of Western Africa. Bull Environ Contam Toxicol 74:988-995

Storelli MM (2008) Potential human health risks from metals ( $\mathrm{Hg}, \mathrm{Cd}$, and $\mathrm{Pb}$ ) and polychlorinated biphenyls (PCBs) via seafood consumption: estimation of target hazard quotients (THQs) and toxic equivalents (TEQs). Food Chem Toxicol 46:2782-2788

Suhaimi F, Wong SP, Lee VLL, Low LK (2005) Heavy metals in fish and shellfish found in local wet markets. Singap J Prim Ind 32:1-18

Tariq J, Jaffar M, Moazzam M (1991) Concentration correlations between major cations and heavy metals in fish from the Arabian Sea. Mar Pollut Bull 22:562-565

Topping G (1973) Heavy metals in fish from Scottish waters. Aquaculture 1:373-377

UNEP (1999) Overview of land-based sources and activities affecting the marine, coastal and associated freshwater environment in the West and Central African Region. UNEP Regional Seas Reports and Studies 171

UNEP (2006) Marine and coastal ecosystems and human wellbeing: a synthesis report based on the findings of the Millennium Ecosystem Assessment. UNEP 76

Uysal K, Emre Y, Köse E (2008) The determination of heavy metal accumulation ratios in muscle, skin and gills of some migratory fish species by inductively coupled plasma-optical emission spectrometry (ICP-OES) in Beymelek Lagoon (Antalya/Turkey). Microchem J 90:67-70

Vieira C, Morais S, Ramos S, Delerue-Matos C, Oliveira MBPP (2011) Mercury, cadmium, lead and arsenic levels in three pelagic fish species from the Atlantic Ocean: intra-and inter-specific variability and human health risks for consumption. Food Chem Toxicol 49:923-932

Vu CT, Lin C, Yeh G, Villanueva MC (2017) Bioaccumulation and potential sources of heavy metal contamination in fish species in Taiwan: assessment and possible human health implications. Environ Sci Pollut Res 24:19422-19434

\section{Publisher's Note}

Springer Nature remains neutral with regard to jurisdictional claims in published maps and institutional affiliations. 